\title{
Crystal Structures of Peptide Enantiomers and Racemates: Probing Conformational Diversity in Heterochiral Pro-Pro Sequences
}

Indranil Saha, ${ }^{1}$ Bhaswati Chatterjee, ${ }^{2}$ Narayanaswamy Shamala, ${ }^{1}$ Padmanabhan Balaram ${ }^{2}$

${ }^{1}$ Department of Physics, Indian Institute of Science, Bangalore 560012, India

${ }^{2}$ Molecular Biophysics Unit, Indian Institute of Science, Bangalore 560012, India

Received 19 December 2007; revised 27 February 2008; accepted 27 February 2008

Published online 11 March 2008 in Wiley InterScience (www.interscience.wiley.com). DOI 10.1002/bip.20982

\section{ABSTRACT:}

Multiple conformational states in heterochiral diproline sequences have been characterized in the solid state by the determination of the crystal structures of seven tripeptides in enantiomeric and racemic forms. The sequences of the type Piv- ${ }^{D}$ Pro- ${ }^{L}$ Pro- ${ }^{D} X x x-N H M e(D-L-D) ~\left[{ }^{D} X x x=\right.$ ${ }^{D}$ Val 1, ${ }^{D}$ Leu 3, and ${ }^{D}$ Phe 5] and their corresponding enatiomeric L-D-L sequences $\left[{ }^{L} X x x={ }^{L}\right.$ Val $2,{ }^{L}$ Leu 4, and ${ }^{L} P$ he 6] have been investigated. Single crystals have been obtained for the pure enantiomers 1, 2, 3, 4 and for the racemates $1 / 2,3 / 4$, and 5/6. For $X x x=L e u$, mirror image conformations (type II/II' $\beta$-turns) at Pro-Leu segment are obtained. For Xxx $=$ Val, ${ }^{L}$ Pro- ${ }^{D}$ Pro type II $\beta$-turn in 2 and an open/extended structure is obtained in the solvated form of the enantiomer 1 . For $X x x=$ Phe, suitable crystals could not be obtained for enatiomeric peptides. The racemate 5/6 revealed a cis peptide bond between the diproline segment with the absence of any intramolecular hydrogen bonds. Crystal structures of enantiomers and racemates prove useful in characterizing the multiple conformational states that are accessible to Pro-Pro segments. (C) 2008 Wiley Periodicals, Inc. Biopolymers (Pept Sci) 90: 537-543, 2008.

Correspondence to: Prof. Narayanaswamy Shamala; e-mail: shamala@physics.iisc. ernet.in or Prof. Padmanabhan Balaram; e-mail: pb@mbu.iisc.ernet.in Contract grant sponsors: Council of Scientific and Industrial Research and Program Support; IRHPA Department of Biotechnology, India (C) 2008 Wiley Periodicals, Inc.
Keywords: diproline peptides; peptide enantiomers; peptide racemates; molecular conformation; conformational variability; $X$-ray diffraction

This article was originally published online as an accepted preprint. The "Published Online" date corresponds to the preprint version. You can request a copy of the preprint by emailing the Biopolymers editorial office at biopolymers@wiley. com

\section{INTRODUCTION}

n 1989 Alan Mackay made the intriguing suggestion that racemic proteins should crystallize in centro-symmetric fashion, resulting in a simplification of the problem of phase determination. Mackay noted "that the outcome of the Second World War turned on this issue, as the German Enigma coding machine was made centro-symmetrical for administrative convenience," a weakness that allowed "an entry to the decipherment of Enigma, which perhaps ultimately led to the military defeat of the Axis." He added insightfully that "Probably no crystallographers were involved on either side." ${ }^{1}$ Subsequently, several reports have described the structure determination of racemic forms of proteins and peptides produced by chemical synthesis. ${ }^{2}$ In exploring multiple conformational states of oligopeptides we have often encountered difficulties in crystallization of flexible peptides. The task of characterizing different conformational states of peptides in crystals is also facilitated by exploring conditions under which polymorphic forms are generated. Ideally, distinctly different crystal forms may provide an opportunity for capturing widely different structural states (conformational polymorphism). The definition of conformational polymorphism can be ambiguous. In the case of oligopeptides, molecules can crystallize in different crystal forms with similar backbone conformations over 
much of the peptide chain. Structural variations are often observed at the termini and in side-chain conformations. Examples of dramatic backbone conformational differences in polymorphic crystal forms are rare. ${ }^{3-5}$ It is in this context that we have turned our attention to the study of peptide racemates.

Di-proline peptides have attracted considerable recent attention because of their ability to nucleate stable secondary structures in short peptides. Homochiral $\left({ }^{\mathrm{L}}\right.$ Pro- ${ }^{\mathrm{L}}$ Pro) sequences have been advanced as helix forming templates, ${ }^{6}$ whereas heterochiral ( $\left.{ }^{\mathrm{D}} \mathrm{Pro}-{ }^{\mathrm{L}} \mathrm{Pro}\right)$ sequences have been shown to be strong $\beta$-hairpin nucleators. ${ }^{7}$ Even though proline is the most conformationally-restricted residue in proteins, multiple states corresponding to different values of the torsion angle $\psi$ are available to the proline residue. ${ }^{8}$ In ${ }^{\text {L }}$ Pro residues, two major conformational states have been widely observed: the polyproline-II $\left(\mathrm{P}_{\mathrm{II}}\right)$ conformation $\left(\phi=-60^{\circ}\right.$, $\left.\psi=120^{\circ}\right)$ and the left-handed helical conformation $(\phi=$ $\left.-60^{\circ}, \psi=-30^{\circ}\right)$. In addition, the $\mathrm{C}_{7}$ or $\gamma$-turn conformation $\left(\phi=-70^{\circ}, \psi=70^{\circ}\right)$ has also been observed. In XxxPro sequences the occurrence of cis peptide bonds further enhances the range of energetically accessible conformations. Pro-Pro peptides are therefore capable of exhibiting significant conformational diversity. We have employed the device of studying pure enantiomers and racemates to probe the structure space of tripeptides of the type $\mathrm{Piv}^{-}{ }^{\mathrm{D}} \mathrm{Pro}_{-}^{-}{ }^{\mathrm{L}}$ Pro- ${ }^{\mathrm{D}} \mathrm{Xxx}-\mathrm{NHMe} / \mathrm{Piv}_{-}{ }^{\mathrm{L}}$ Pro- ${ }^{\mathrm{D}}$ Pro- ${ }^{\mathrm{L}} \mathrm{Xxx}-\mathrm{NHMe}$. Recent interest in the conformational properties of ${ }^{\mathrm{D}} \mathrm{Pro}-{ }^{\mathrm{L}} \mathrm{Pro}-{ }^{\mathrm{D}} \mathrm{Xxx}$ sequences have been stimulated by the demonstration that $\beta$ hairpins can be nucleated by a three residue connecting loop when $\mathrm{Xxx}={ }^{\mathrm{D}}$ Ala. ${ }^{9}$

Six peptides with $\mathrm{Xxx}={ }^{\mathrm{D}}$ Val 1, ${ }^{\mathrm{L}}$ Val 2, ${ }^{\mathrm{D}}$ Leu 3, ${ }^{\mathrm{L}}$ Leu 4, ${ }^{\mathrm{D}} \mathrm{Phe} 5$, and ${ }^{\mathrm{L}} \mathrm{Phe} 6$ have been investigated. Crystallization attempts were made with the pure enantiomers $D-L-D$ (peptides $1,3,5$ ) and $L-D-L$ (peptides $2,4,6$ ). In addition, the racemates $1 / 2,3 / 4$, and $5 / 6$ were prepared by mixing equimolar mixtures of the two individual enantiomers.

\section{EXPERIMENTAL SECTION}

\section{Peptide Synthesis}

Peptides were synthesized by conventional solution phase methods using a fragment condensation strategy. The pivaloyl (Piv) group was used for the $\mathrm{N}$-terminus, while the $\mathrm{C}$-terminus was blocked as $\mathrm{N}$-methylamide. Couplings were mediated by dicyclohexylcarbodiimide/1-hydroxybenzotriazole (DCC/HOBT). The synthesis of peptides was achieved by the condensation of Piv- ${ }^{\mathrm{D}} \mathrm{Pro}-{ }^{\mathrm{L}} \mathrm{Pro}-\mathrm{OH} / \mathrm{Piv}-$ ${ }^{\mathrm{L}}$ Pro- ${ }^{\mathrm{D}}$ Pro-OH with fragment $\mathrm{Xxx}-\mathrm{OMe}\left(\mathrm{Xxx}={ }^{\mathrm{D}}\right.$ Val 1, ${ }^{\mathrm{L}}$ Val 2, ${ }^{\mathrm{D}}$ Leu 3, ${ }^{\mathrm{L}}$ Leu 4, ${ }^{\mathrm{D}}$ Phe 5, and ${ }^{\mathrm{L}} \mathrm{Phe}$ 6). All the six tripeptide methyl esters were converted to their respective $\mathrm{N}$-methylamides by saturat- ing the methanolic solution of the tripeptide esters with methylamine gas. The final peptide products were purified by silica-gel column chromatography followed by HPLC $\left(\mathrm{C}_{18}, 5-10 \mu\right)$, employing methanol-water gradients. The homogeneity of the purified peptides was ascertained by analytical HPLC. Optical rotation parameters and the melting point of the peptides reported in this article are as follows:

Piv- ${ }^{\mathrm{D}}$ Pro- ${ }^{\mathrm{L}}$ Pro- ${ }^{\mathrm{D}}$ Val-NHMe $1[\alpha]^{24}{ }_{\mathrm{D}}=-62.5(c=0.88$, $\left.\mathrm{CH}_{3} \mathrm{OH}\right)$; mp: $100.2^{\circ} \mathrm{C}$, Piv- ${ }^{\mathrm{L}}$ Pro- ${ }^{\mathrm{D}}$ Pro- ${ }^{\mathrm{L}}$ Val-NHMe $2[\alpha]^{25}{ }_{\mathrm{D}}=+$ $62.3\left(c=1.46, \mathrm{CH}_{3} \mathrm{OH}\right) ; \mathrm{mp:} 99.3^{\circ} \mathrm{C}$, Piv- ${ }^{\mathrm{D}}$ Pro- ${ }^{\mathrm{L}}$ Pro- ${ }^{\mathrm{D}}$ Leu-NHMe $3[\alpha]^{23}{ }_{\mathrm{D}}=-40.0\left(c=1.00, \mathrm{CH}_{3} \mathrm{OH}\right) ; \mathrm{mp}: 106.4^{\circ} \mathrm{C}$, Piv- ${ }^{\mathrm{L}} \mathrm{Pro}-$ ${ }^{\mathrm{D}}$ Pro- ${ }^{\mathrm{L}}$ Leu-NHMe $4[\alpha]^{24}{ }_{\mathrm{D}}=+52.0\left(c=1.5, \mathrm{CH}_{3} \mathrm{OH}\right)$; mp: $105.9^{\circ} \mathrm{C}$, Piv- ${ }^{\mathrm{D}}$ Pro- ${ }^{\mathrm{L}}$ Pro- ${ }^{\mathrm{D}}$ Phe-NHMe $5[\alpha]^{23} \mathrm{D}=-34.0(c=0.8$, $\left.\mathrm{CH}_{3} \mathrm{OH}\right)$; gummy, Piv- ${ }^{\mathrm{L}}$ Pro- ${ }^{\mathrm{D}}$ Pro- ${ }^{\mathrm{L}}$ Phe-NHMe $6[\alpha]^{23}{ }_{\mathrm{D}}=+39.0(c$ $=1.00, \mathrm{CH}_{3} \mathrm{OH}$ ); gummy, Racemic mixture of Piv- ${ }^{\mathrm{D}}$ Pro- ${ }^{\mathrm{L}}$ Pro- ${ }^{\mathrm{D}}$ Val$\mathrm{NHMe}+\mathrm{Piv}^{\mathrm{L}}$ Pro- ${ }^{\mathrm{D}}$ Pro- ${ }^{\mathrm{V}}$ Val-NHMe $1 / 2 \mathrm{mp}: 150.2^{\circ} \mathrm{C}$, Racemic mixture of Piv- ${ }^{\mathrm{D}}$ Pro- $-{ }^{\mathrm{L}}$ Pro- $-{ }^{\mathrm{D}} \mathrm{Leu}-\mathrm{NHMe}+\mathrm{Piv}^{\mathrm{L}}{ }^{\mathrm{D}}{ }^{2}-{ }^{\mathrm{D}}$ Pro- ${ }^{\mathrm{L}} \mathrm{Leu}-$ NHMe 3/4 mp: $130.4^{\circ} \mathrm{C}$, Racemic mixture of Piv- ${ }^{\mathrm{D}}$ Pro- ${ }^{\mathrm{L}}$ Pro- ${ }^{\mathrm{D}} \mathrm{Phe}-$ $\mathrm{NHMe}+\mathrm{Piv}^{-}{ }^{\mathrm{L}}$ Pro- ${ }^{\mathrm{D}}$ Pro- $-{ }^{\mathrm{L}}$ Phe-NHMe $5 / 6 \mathrm{mp}: 115.2^{\circ} \mathrm{C}$.

Single crystals were obtained by slow evaporation of pure enantiomers or racemic mixtures from petroleum ether/ethyl acetate, methanol/water and $\mathrm{CHCl}_{3}$-DMSO.

\section{X-Ray Diffraction}

Single crystals suitable for X-ray diffraction were obtained in the cases of peptides $1,2,3,4,1 / 2,3 / 4$, and 5/6. In the case of $\mathrm{Xxx}$ $=$ Phe $(5,6)$, the pure enantiomers failed to yield crystals. X-ray diffraction data were collected at room temperature on a Bruker AXS SMART APEX CCD diffractometer using Mo $\mathrm{K} \alpha$ radiation ( $\lambda$ $=0.71073 \AA$ ). The $\omega$-scan type was used. All the structures were solved by direct methods using SHELXS- $97^{10 a}$ and refined against $F^{2}$, with full-matrix least-squares methods using SHELXL-97. ${ }^{10 b}$ Nonhydrogen atoms were refined isotropically followed by full-matrix anisotropic least squares refinement. The crystal and diffraction parameters for the peptides solved are given in Table I In the crystal structure of peptide $\mathbf{1}$, valine and the C-terminal blocking group $\mathrm{N}$ methylamide (NHMe) are disordered over two positions with an occupancy of 0.42 in one site (Chain A: atoms C3A, C3', O3, N4, $\mathrm{C} 1 \mathrm{M}, \mathrm{C} 3 \mathrm{~B}, \mathrm{C} 3 \mathrm{G}$, and $\mathrm{C} 3 \mathrm{D})$ and an occupancy of 0.58 in the other site (Chain B : atoms C33A, C33', O33, N41, C11M, C33B, C33G, and $\mathrm{C} 33 \mathrm{D})$. However, as both the chains were unacceptably close, refinement was effected using occupancy at a single site only. Notably, a water molecule with an occupancy of 0.42 is associated with only chain A of the molecule and not chain B. In the racemic mixture $\mathbf{1} / \mathbf{2}$, a similar method was adopted for the refinement of a water molecule with an occupancy of 0.74 where symmetry related water molecules were unacceptably close. In loosely packed crystals, solvent (water occupancies) at available sites are often fractional. Orientational disorder can also result in the inability to locate definitive positions. In peptide 2 , the hydrogen atom $(\mathrm{H})$ bonded to Pro $\mathrm{C} 1 \mathrm{~A}$ Pro C2A and NHMe N4 were located from difference Fourier map. In peptide $\mathbf{3} \mathbf{4}$, the hydrogen atom $(\mathrm{H})$ bonded to Pro $\mathrm{C} 1 \mathrm{~A}$; Pro C2A; Leu C3A; Leu N3; Leu C3B; and Leu C3G were located from difference Fourier map. The remaining hydrogens in all the other peptide structures were fixed geometrically using the riding atom model in the idealized positions and refined in the final cycle as riding over the heavier atom to which they were bonded. Crystallographic data (excluding structure factors) have been deposited at 


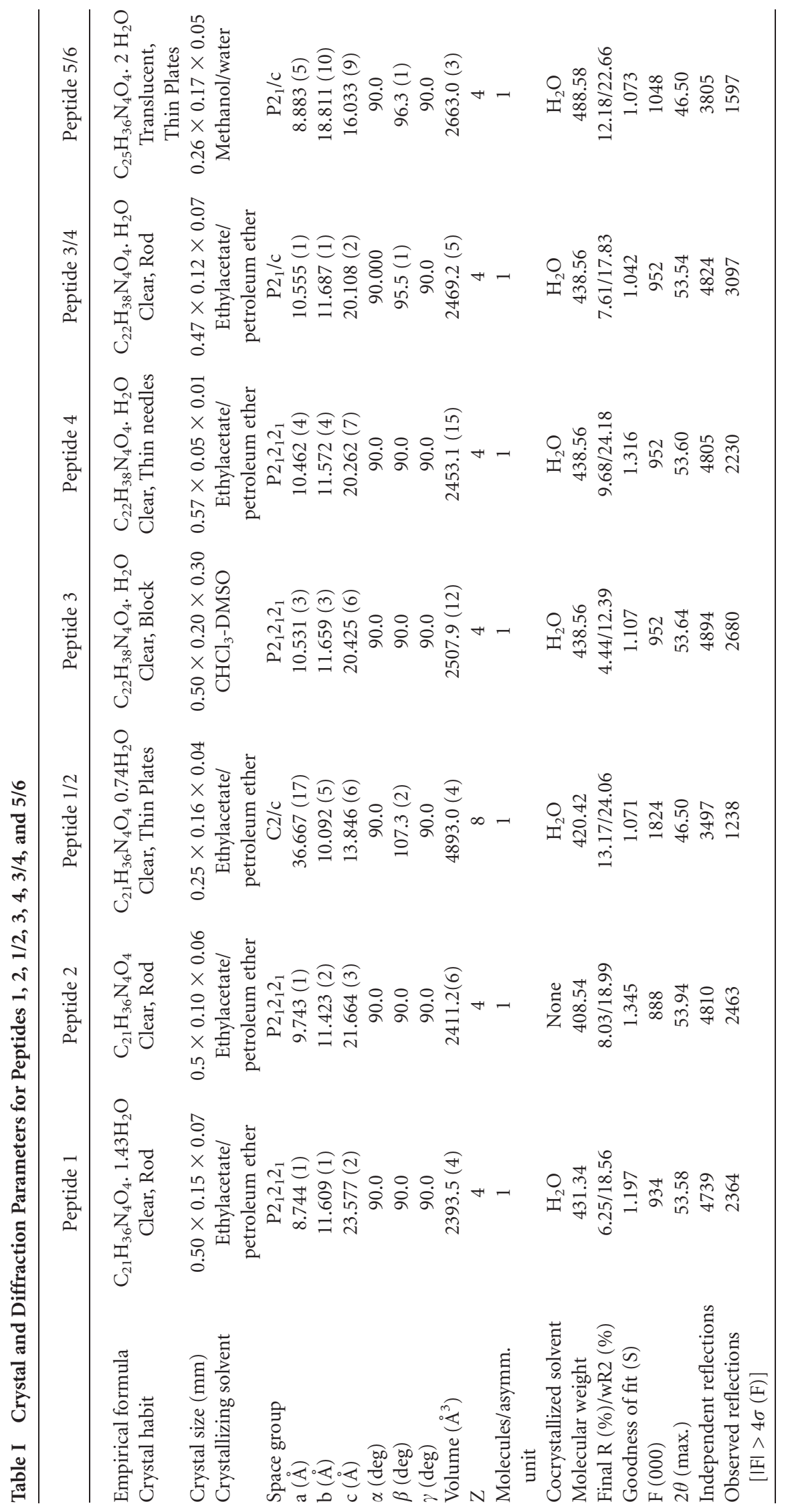



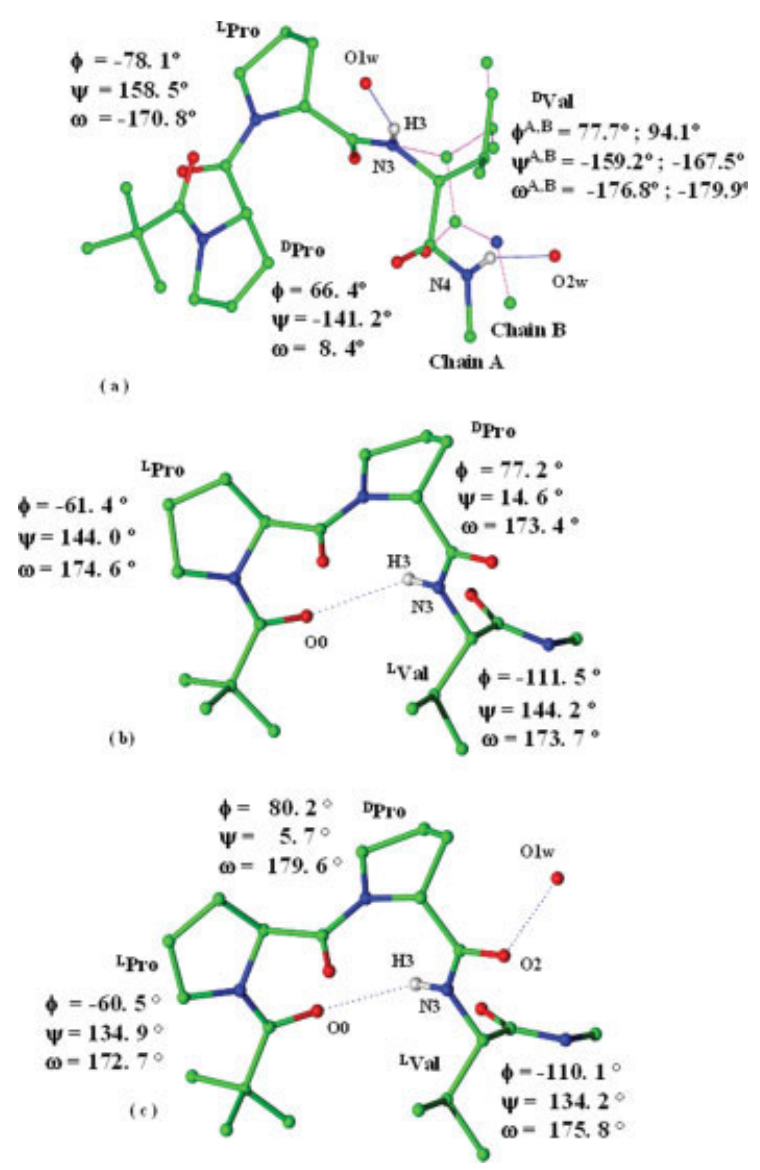

FIGURE 1 Asymmetric unit and molecular conformation of a) Piv- ${ }^{\mathrm{D}}$ Pro- ${ }^{\mathrm{L}}$ Pro- ${ }^{\mathrm{D}}$ Val-NHMe. b) Piv- ${ }^{\mathrm{L}}$ Pro- ${ }^{\mathrm{D}}$ Pro- ${ }^{\mathrm{L}}$ Val-NHMe. c) Racemic mixture of Piv- $^{\mathrm{D}}{ }^{\mathrm{Pro}}-{ }^{\mathrm{L}}{ }^{\mathrm{P}}{ }^{-}{ }^{-}{ }^{\mathrm{D}}$ Val-NHMe + Piv- ${ }^{\mathrm{L}}$ Pro${ }^{D}$ Pro- ${ }^{L}$ Val-NHMe. (Only the $L-D-L$ enantiomer has been shown). Hydrogen bonds are shown as dotted lines.

the Cambridge Crystallographic Data Centre with deposition numbers: 1 CCDC 611007; 2 CCDC 611008; 1/2 CCDC 611009; 3 CCDC 611010; 4 CCDC 611011; 3/4 CCDC 611012; 5/6 CCDC 611013. These data can be obtained free of charge from the Cambridge Crystallographic Data Centre, 12 Union Road, Cambridge, CB21EZ, U.K., Telephone: $(+44) 1223-762-910$, Fax: $(+44) 1223-336-$ 033 or via the website www.ccdc.cam.ac.uk/conts/retrieving.html (e-mail: deposit@ccdc.cam.ac.uk).

\section{RESULTS AND DISCUSSION}

Conformational Analysis of Peptides 1, 2, and 1/2

Figure 1 shows the comparison of the molecular conformations observed in the crystals of the enantiomers 1 and 2 and the racemate $1 / 2(\mathrm{Xxx}=\mathrm{Val}) .1$ crystallized as the hydrate while 2 lacks any co-crystallized water molecule. Notably, considerable differences are observed in the backbone conformations of the two enantiomers presumably facilitated by intermolecular hydrogen bonding of the central peptide unit
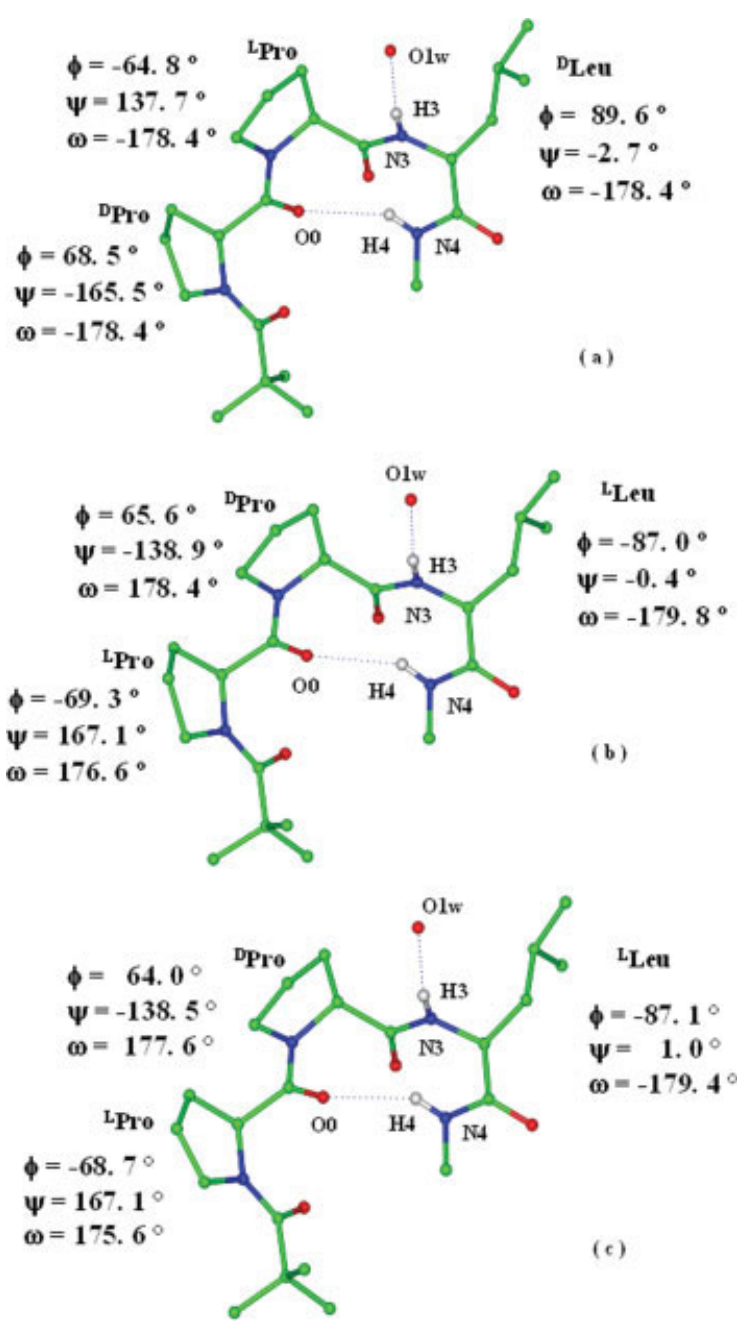

FIGURE 2 Asymmetric unit and molecular conformation of a) Piv- ${ }^{\mathrm{D}}$ Pro- ${ }^{\mathrm{L}}$ Pro- $-{ }^{\mathrm{D}}$ Leu-NHMe. b) Piv- ${ }^{\mathrm{L}}$ Pro- $-{ }^{\mathrm{D}}$ Pro- ${ }^{\mathrm{L}}$ Leu-NHMe. c) Racemic mixture of Piv- ${ }^{\mathrm{D}}$ Pro- ${ }^{\mathrm{L}}$ Pro- ${ }^{\mathrm{D}} \mathrm{Leu}-\mathrm{NHMe}+$ Piv- ${ }^{\mathrm{L}}$ Pro${ }^{\mathrm{D}}$ Pro- ${ }^{\mathrm{L}} \mathrm{Leu}-\mathrm{NHMe}$. (Only the $L-D-L$ enantiomer has been shown). Hydrogen bonds are shown as dotted lines.

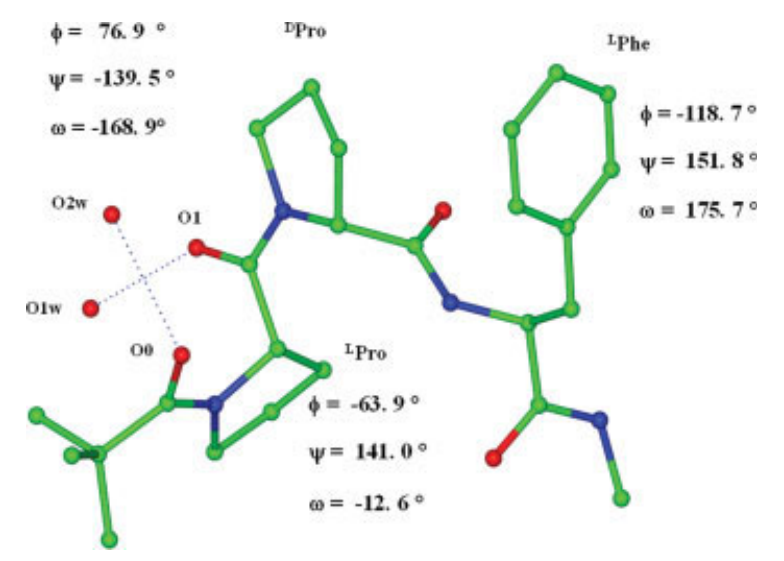

FIGURE 3 Asymmetric unit and molecular conformation of racemic mixture of Piv- ${ }^{\mathrm{D}}$ Pro- $-{ }^{\mathrm{L}}$ Pro- $-{ }^{\mathrm{D}}$ Phe-NHMe + Piv- ${ }^{\mathrm{L}}$ Pro- $-{ }^{\mathrm{D}}$ Pro- $-{ }^{\mathrm{L}}$ PheNHMe. (Only the $L-D-L$ enantiomer has been shown). Hydrogen bonds are shown as dotted lines. 


\begin{tabular}{|c|c|c|c|c|c|c|c|}
\hline \multirow[b]{2}{*}{ Donor } & \multirow[b]{2}{*}{ Acceptor } & N/C/O... & \multirow[b]{2}{*}{$\begin{array}{r}\text { H. ..O } \\
(\AA)\end{array}$} & \multirow[b]{2}{*}{$\begin{array}{c}\mathrm{C}=\underset{\mathrm{O} . . \mathrm{H}}{(\mathrm{deg})}\end{array}$} & \multirow[b]{2}{*}{$\begin{aligned} \mathrm{C}= & \mathrm{O} \ldots \mathrm{N} \\
& (\mathrm{deg})\end{aligned}$} & \multirow[b]{2}{*}{$\begin{array}{c}\mathrm{O} \ldots \mathrm{H}-\mathrm{N} \\
(\mathrm{deg})\end{array}$} & \multirow[b]{2}{*}{$\begin{array}{c}\mathrm{C}-\mathrm{H} \ldots \mathrm{O} \\
(\mathrm{deg})\end{array}$} \\
\hline & & $\begin{array}{c}\text { Donor/ } \\
\text { Acceptor }(\AA)\end{array}$ & & & & & \\
\hline \multicolumn{8}{|c|}{ Piv- ${ }^{\mathrm{D}}$ Pro- ${ }^{\mathrm{L}}$ Pro- ${ }^{\mathrm{D}}$ Val NHMe $(\mathbf{1})$} \\
\hline \multicolumn{8}{|c|}{ Intermolecular } \\
\hline $\mathrm{N}(3)$ & O1w & 3.023 & 2.100 & & & 163.89 & \\
\hline $\mathrm{N}(4)$ & $\mathrm{O} 2 \mathrm{w}$ & 2.782 & 1.995 & & & 151.82 & \\
\hline O1w & $\mathrm{O}(0)^{\mathrm{a}}$ & 2.940 & & & & & \\
\hline $\mathrm{O} 1 \mathrm{w}$ & $\mathrm{O}(1)^{\mathrm{b}}$ & 2.821 & & & & & \\
\hline $\mathrm{O} 2 \mathrm{w}$ & $\mathrm{O} 1 \mathrm{w}^{\mathrm{c}}$ & 3.368 & & & & & \\
\hline \multicolumn{8}{|c|}{ Piv- ${ }^{\mathrm{L}}$ Pro- ${ }^{\mathrm{D}}$ Pro- ${ }^{\mathrm{L}}$ Val-NHMe (2) } \\
\hline \multicolumn{8}{|c|}{ Intramolecular } \\
\hline $4 \rightarrow 1 \mathrm{~N}(3)$ & $\mathrm{O}(0)$ & 3.388 & 2.648 & 142.32 & 138.71 & 144.93 & \\
\hline \multicolumn{8}{|l|}{ Intermolecular } \\
\hline $\mathrm{N}(4)$ & $\mathrm{O}(2)^{\mathrm{d}}$ & 2.833 & 2.062 & 132.33 & 135.11 & 164.51 & \\
\hline \multicolumn{8}{|c|}{ Racemic mixture of Piv- ${ }^{\mathrm{D}}$ Pro- ${ }^{\mathrm{L}}$ Pro- ${ }^{\mathrm{D}}$ Val-NHMe + Piv- ${ }^{\mathrm{L}}$ Pro- $-{ }^{\mathrm{D}}$ Pro- ${ }^{\mathrm{L}}$ Val-NHMe $(\mathbf{1} / \mathbf{2})$} \\
\hline \multicolumn{8}{|l|}{ Intramolecular } \\
\hline $4 \rightarrow 1 \mathrm{~N}(3)$ & $\mathrm{O}(0)$ & 3.279 & 2.490 & 141.64 & 137.93 & 156.45 & \\
\hline \multicolumn{8}{|l|}{ Intermolecular } \\
\hline $\mathrm{N}(4)$ & $\mathrm{O}(1)^{\mathrm{e}}$ & 2.883 & 2.026 & 149.43 & 150.98 & 174.71 & \\
\hline O1w & $\mathrm{O}(2)^{\mathrm{f}}$ & 2.954 & & & & & \\
\hline \multicolumn{8}{|c|}{ Piv- ${ }^{\mathrm{D}}$ Pro- ${ }^{\mathrm{L}}$ Pro- ${ }^{\mathrm{D}}$ Leu-NHMe $(3)$} \\
\hline \multicolumn{8}{|c|}{ Intramolecular } \\
\hline $4 \rightarrow 1 \mathrm{~N}(4)$ & $\mathrm{O}(1)$ & 3.184 & 2.411 & 139.17 & 139.89 & 149.90 & \\
\hline \multicolumn{8}{|l|}{ Intermolecular } \\
\hline $\mathrm{N}(3)$ & O1w & 2.857 & 2.011 & & & 167.99 & \\
\hline $\mathrm{O} 1 \mathrm{w}$ & $\mathrm{O}(0)^{\mathrm{g}}$ & 2.769 & & & & & \\
\hline O1w & $\mathrm{O}(2)^{\mathrm{g}}$ & 2.764 & & & & & \\
\hline \multicolumn{8}{|c|}{ Piv- ${ }^{\mathrm{L}}$ Pro- ${ }^{\mathrm{D}}$ Pro- ${ }^{\mathrm{L}} \mathrm{Leu}-\mathrm{NMe}(\mathbf{4})$} \\
\hline Intramolecular & & & & & & & \\
\hline $4 \rightarrow 1 \mathrm{~N}(4)$ & $\mathrm{O}(1)$ & 3.175 & 2.405 & 139.76 & 140.07 & 149.30 & \\
\hline Intermolecular & & & & & & & \\
\hline $\mathrm{N}(3)$ & O1w & 2.881 & 1.982 & & & 168.96 & \\
\hline O1w & $\mathrm{O}(0)^{\mathrm{h}}$ & 2.790 & & & & & \\
\hline $\mathrm{O} 1 \mathrm{w}$ & $\mathrm{O}(2)^{\mathrm{h}}$ & 2.764 & & & & & \\
\hline Racemic mixtu & ${ }^{\mathrm{D}}$ Leu-NHM & Piv- ${ }^{\mathrm{L}}$ Pro- ${ }^{\mathrm{D}}$ Pro- ${ }^{\mathrm{I}}$ & u-NHMe & & & & \\
\hline Intramolecular & & & & & & & \\
\hline $4 \rightarrow 1 \mathrm{~N}(4)$ & $\mathrm{O}(1)$ & 3.087 & 2.316 & 139.98 & 141.18 & 149.36 & \\
\hline Intermolecular & & & & & & & \\
\hline $\mathrm{N}(3)$ & O1w & 2.865 & 2.025 & & & 165.46 & \\
\hline O1w & $\mathrm{O}(0)^{\mathrm{i}}$ & 2.767 & & & & & \\
\hline O1w & $\mathrm{O}(2)^{\mathrm{i}}$ & 2.792 & & & & & \\
\hline Racemic mixts & ${ }^{\mathrm{D}} \mathrm{Phe}-\mathrm{NH}$ & Piv- ${ }^{\mathrm{L}}$ Pro- ${ }^{\mathrm{D}}$ Pro- ${ }^{\mathrm{I}}$ & e-NHMe & & & & \\
\hline Intramolecular & & & & & & & \\
\hline $4 \rightarrow 1 \mathrm{~N}(3)$ & $\mathrm{O}(0)$ & 3.144 & 2.382 & 138.20 & 132.01 & 147.97 & \\
\hline $4 \rightarrow 1 \mathrm{~N}(4)$ & $\mathrm{O}(1)$ & 3.109 & 2.285 & 120.93 & 126.06 & 160.37 & \\
\hline Intermolecular & & & & & & & \\
\hline O1w & $\mathrm{O} 2 \mathrm{w}^{\mathrm{j}}$ & 2.930 & & & & & \\
\hline O1w & $\mathrm{O}(2)$ & 2.731 & & & & & \\
\hline $\mathrm{O} 2 \mathrm{w}$ & $\mathrm{O}(3)$ & 3.148 & & & & & \\
\hline O1w & $\mathrm{O} 2 \mathrm{w}$ & 3.351 & & & & & \\
\hline
\end{tabular}

${ }^{\text {a }}$ Related by symmetry $x+1 / 2,-y+1 / 2,-z$.

${ }^{\mathrm{b}}$ Related by symmetry $x+1, y, z$.

${ }^{\mathrm{c}}$ Symmetry related by $-x+1, y-1 / 2,-z+1 / 2+1$.

d Related by symmetry $x+1 / 2,-y+1 / 2,-z+2$.

e Symmetry related by $x,-y, z+1 / 2$.

${ }^{\mathrm{f}}$ Symmetry related by $-x, y,-z+1 / 2$.

gelated by symmetry $-x, y-1 / 2,-z+1 / 2$.

${ }^{\mathrm{h}}$ Related by symmetry $-x+1, y-1 / 2,-z+1 / 2+1$.

${ }^{\mathrm{i}}$ Symmetry related by $-x, y-1 / 2,-z+1 / 2$.

${ }^{j}$ Symmetry related by $x+1 / 2,-y+1 / 2+1,-z+1$. 
of 1 to the water molecule O1w. In the $D-L-D$ peptide, the ${ }^{\mathrm{D}}$ Pro-Pro peptide bond adopts a cis $\left(\omega=8.4^{\circ}\right)$ geometry and both the proline residues adopt a semi-extended conformation, with the molecule lacking any intramolecular hydrogen bond. In contrast, in the $L-D-L$ enantiomer, the ${ }^{\mathrm{L}}$ Pro- ${ }^{\mathrm{D}}$ Pro segment forms a type II $\beta$-turn conformation with an intramolecular 4 to 1 hydrogen bond between the pivaloyl $\mathrm{C}=\mathrm{O}$ and the valine $\mathrm{NH}$ groups. In principle, the enantiomers might be expected to yield mirror image crystals, formed by molecules with identical conformations. The crystals of 1 and 2 illustrate conformational variability which may be observed when comparing solvent free crystals with solvates ("pseudo polymorphism"). ${ }^{11}$ Figure $1 c$ shows the molecular conformation of the tripeptide in the racemic crystals of $1 / 2$. The asymmetric unit reveals a peptide folded into a type II $\beta$-turn conformation. This is almost a mirror image to the structure observed in the $L-D-L$ enantiomer 2.

\section{Conformational Analysis of Peptides 3, 4, and 3/4}

The structures of the enantiomers 3 and $\mathbf{4}$ and the racemate $3 / 4(\mathrm{Xxx}=\mathrm{Leu})$ are shown in Figure 2. In the case of peptide 3 , the ${ }^{\mathrm{D}}$ Pro residue adopts a semi-extended conformation with the formation of a type II $\beta$-turn at the ${ }^{\mathrm{L}}$ Pro- ${ }^{\mathrm{D}} \mathrm{Leu}$ segment. Investigation of the backbone conformations for peptide 4 reveals that it adopts a nearly identical mirror image structure to that of peptide 3. An interesting feature in both the structures is that the heterochiral Pro-Pro segment is semi-extended while type II (3) or II' (4) $\beta$-turn conformations are observed at the Pro-Leu segment. The central peptide unit in the $\beta$-turn is hydrated in both the peptides, a commonly observed feature in proteins and peptides. ${ }^{12}$ In principle, in the $D-L-D / L-D-L$ sequences, isolated $\beta$-turns of the $D L$ or $L D$ types are possible. ${ }^{13}$ While one type has been established for $\mathrm{Xxx}=\mathrm{Val}$, the other is observed for $\mathrm{Xxx}=$ Leu. The crystal structure of the racemate $3 / 4$ reveals a molecular conformation that is almost identical to that observed in the enantiomers.

\section{Conformational Analysis of Peptide 5/6}

In the case of $\mathrm{Xxx}=$ Phe, crystals could only be obtained for the racemate $5 / 6$. The asymmetric unit contains a single peptide molecule which adopts an open structure lacking any intramolecular hydrogen bond. Both the prolines adopt a semi-extended backbone conformation with the Phe residue adopting an extended conformation as shown in Figure 3. Both the water molecules are intermolecularly hydrogen bonded to $\mathrm{C}=\mathrm{O}$ belonging to Piv group and Pro(1). Notably, this structure is remarkably similar to that of peptide 1 in its backbone conformation. A list of all intra- and inter- molecular hydrogen bonds in all the peptides that have been discussed in this paper are listed in Table II.

\section{CONCLUSIONS}

This study was undertaken to explore the possibility of trapping distinct conformational segments of the diproline segments in crystals by generating racemic centro-symmetric crystals in which packing effects may be appreciably different from those observed in the crystals of individual pure enantiomeric peptides. In the case of the peptide Piv-Pro-ProLeu-NHMe, both the enantiomers and the racemate yielded mirror image conformations. In contrast, in the related sequence Piv-Pro-Pro-Val-NHMe, the two enantiomeric peptides crystallized in two different polymorphic forms. In one case an anhydrous crystal was obtained while in the other case the crystal structure contains trapped water molecules. The crystal structures of the peptides $\mathbf{1}$ and $\mathbf{2}$ may be considered as an example of "pseudo polymorphism" resulting from solvation. This example illustrates the difficulties in controlling crystallization conditions precisely when multiple modes of crystal nucleation are possible. The case of the peptides $\mathbf{5}$ and $\mathbf{6}$ is an interesting example where the individual enantiomers were recalcitrant to crystallization, while single crystals were readily obtained in the case of the racemate 5/6. The ability of the racemates to pack more effectively than the pure enantiomers is a feature that has been recognized even in Kitaigorodski's classic analysis of molecular crystals. ${ }^{14}$ The conformational diversity of heterochiral Pro-Pro sequences, is clearly demonstrated by the examples discussed above. A $D-L-D$ sequence $\left(\mathrm{Xxx}={ }^{\mathrm{D}} \mathrm{Ala}\right)$ has been used as a linking three residue loop in a designed $\beta$-hairpin peptide. ${ }^{9}$ In the present study, conformational variations are observed for different Xxx groups. Even more importantly, conformational differences are established for enantiomeric peptides and racemates. These results suggest that the energetic differences between these states is small. Conformational choice can therefore be readily influenced by environmental and sequence effects.

B. Chatterjee was supported by a Senior Research Fellowship of the University Grants Commission.

\section{REFERENCES}

1. Mackay, A. L. Nature 1989, 342, 133.

2. (a) Zawadzke, L. E.; Berg, J. M. Proteins 1993, 16, 301-305; (b) Doi, M.; Inoue, M.; Tomoo, K.; Ishida, T.; Ueda, Y.; Akagi, M.; Urata, H. J Am Chem Soc 1993, 43, 10432-10433; (c) Berg, J. M.; Zawadzke, L. E.; Toniolo, C. Nat Struct Mol Biol 1994, 1, 908-914; (d) Berg, J. M.; Zawadzke, L. E. Curr Opin Biotechnol 1994, 5, 343-345; (e) Doi, M.; Ishibe, A.; Shinozaki, H.; Urata, 
H.; Ishida, T. Int J Pept Protein Res 1994, 43, 325-331; (f) Hung, L. W.; Kohmura, M.; Ariyoshi Y.; Kim, S. H. J Mol Biol 1999, 285, 311-321.

3. Karle, I. L.; Flippen-Anderson, J. L.; Uma, K.; Balaram, P. Biopolymers 1990, 29, 1835-1845.

4. (a) Blundell, T. L.; Hearn, L.; Tickle, I. J.; Palmer, R. A. Science 1979, 205, 220; (b) Camerman, A.; Mastropaolo, D.; Karle, I.; Karle, J.; Camerman, N. Nature 1983, 306, 447-450.

5. Prasad, S.; Mitra, S.; Subramanian, E.; Velmurugan, D.; Balaji Rao, R.; Balaram, P. Biochem Biophys Res Commun 1994, 198, 424-430.

6. (a) Venkatachalapathi, Y. V.; Balaram, P. Nature 1979, 281, 8384; (b) Kemp, D. S.; Boyd, J. G.; Muendel, C. C. Nature 1991, 352, 451-454; (c) Kemp, D. S.; Curran, T. P.; Boyd, J. G.; Allen, T. J. J Org Chem 1991, 56, 6683-6697; (d) Kemp, D. S.; Curran, T. P.; Davis, W. M.; Boyd, J. G.; Muendel, C. J Org Chem 1991, 56, 6672-6682; (e) Job, G. E.; Heitmann, B.; Kennedy, R. J.; Walker, S. M.; Kemp, D. S. Angew Chem Int Ed 2004, 43, 56495651; (f) Heitmann, B.; Job, G. E.; Kennedy, R. J.; Walker, S. M.; Kemp, D. S. J Am Chem Soc 2005, 127, 1690-1704.

7. (a) Sibanda, B. L.; Thornton, J. M. Nature 1985, 316, 170-174; (b) Sibanda, B. L.; Blundell, T. L.; Thornton, J. M. J Mol Bio 1989, 206, 759-777; (c) Hutchinson, E. G.; Thornton, J. M. Protein Sci 1994, 3, 2207-2216; (d) Gunasekaran, K.; Ramakrishnan, C.; Balaram, P. Protein Eng 1997, 10, 1131-1141.
8. Rai, R.; Aravinda, S.; Kanakrajdurai, K.; Raghothama, S.; Shamala, N.; Balaram, P. J Am Chem Soc 2006, 128, 7916-7928.

9. Rai, R.; Raghothama, S.; Balaram, P. J Am Chem Soc 2006, 128, 2675-2681.

10. (a) Sheldrick, G. M. SHELXS-97, A Program for Automatic Solution of Crystal Structures; University of Göttingen: Göttingen, 1997; (b) Sheldrick, G. M. SHELXL-97, Program for the Crystal Structure Refinement; University of Göttingen: Göttingen, 1997.

11. (a) Desiraju, G. R. Cryst Eng Comm 2003, 5, 466-467; (b) Dunitz, J. D. Cryst Eng Comm 2003, 5, 506; (c) Rogers, R. D. Cryst Growth Des 2003, 3, 867; (d) Rogers, R. D. Cryst Growth Des 2004, 4, 10857; (e) Bernstein, J. Cryst Growth Des 2005, 5, 1661-1662; (f) Seddon, K. R. Cryst Growth Des 2004, 4, 1087; (g) Laird, T. Org Process Res Dev 2005, 9, 857; (h) Nangia, A. Cryst Growth Des 2006, 6, 2-4.

12. (a) Rose, G. D.; Young, W. B.; Gierasch, L. M. Nature 1983, 304, 654-657; (b) Aravinda, S.; Harini, V. V.; Shamala, N.; Das, C.; Balaram, P. Biochemistry 2004, 43, 1832-1846.

13. Chandrasekaran, R.; Lakshminarayanan, A.V.; Pandya, U. V.; Ramachandran, G. N. Biochim et Biophys Acta 1973, 303, 14-27.

14. Kitaigorodski, A. I. Molecular Crystals and Molecules; Academic Press: New York, 1973. 